\title{
Managerial Ownership and Financial Performance of the Nigerian Listed Firms: The Moderating Role of Board Independence
}

\begin{abstract}
Abdullahi Sani
Department of Accountancy, Federal Polytechnic Bali, Taraba State, Nigeria, E-mail: abdullahisani13@yahoo.com

Abstract

The existing literature documents inconsistent results regarding the effect of managerial ownership on firms' performance level. This study integrates insights from agency and resource dependency theories and model board independence to account for these indeterminate empirical results that prior research exhibited. Hence, this research aims at investigating the moderating effect of board independence on the relationship between managerial shareholding and financial performance of the Nigerian listed firms. The article analysed the balanced panel data of 71 listed companies covering the period from 2012-2018, by exploiting a generalised method of moments framework. The paper presents evidence of a strong negative relationship between managerial ownership and firm performance level. However, the direct effect of board independence on performance shows a positive but insignificant coefficient. More importantly, evidence from this study suggests that the magnitude and direction of the association between managerial ownership and firm performance depend on the levels of board independence. Thus, revealing that firms with a substantial number of independent directors on their boards are likely to neutralise the entrenchment behaviour that a higher managerial shareholding induces. Consequently, this research recommends that companies should constitute their boards with a considerable number of independent directors to enhance their bottom line.
\end{abstract}

Key words

Managerial Ownership, Firm Performance, Board Independence, Nigerian Listed Firms

\begin{tabular}{|c|c|c|}
\hline Received: & $02 \mathrm{Jul} 2020$ & (C) The Authors 2020 \\
\hline Revised: & 17 Aug 2020 & Published by Human Resource Management Academic Research Society (www.hrmars.com) \\
\hline $\begin{array}{l}\text { Accepted: } \\
\text { ed Online: }\end{array}$ & $\begin{array}{l}16 \text { Sep } 2020 \\
28 \text { Sep } 2020\end{array}$ & $\begin{array}{l}\text { This article is published under the Creative Commons Attribution (CC BY } 4.0 \text { ) license. Anyone may } \\
\text { reproduce, distribute, translate and create derivative works of this article (for both commercial and } \\
\text { non-commercial purposes), subject to full attribution to the original publication and authors. The full } \\
\text { terms of this license may be seen at: http://creativecommons.org/licences/by/4.0/legalcode }\end{array}$ \\
\hline
\end{tabular}

\section{Introduction}

The existing literature extensively investigated the relationship between managerial ownership and firms' financial performance (Cui \& Mak, 2002; Haghighi \& Safari Gerayli, 2020; Short \& Keasey, 1999). Prior studies suggest that managerial shareholding helps in aligning the divergence interests of managers and shareholders (Jensen \& Meckling, 1976; Mustapha \& Ahmad, 2011). Thus, according to this view, managerial ownership empowers managers to design policies aimed at maximising firms' value. On the other side, a stream of the literature contended that managerial ownership promotes information asymmetry, leads to earnings management practices and widens the shareholder-manager agency conflicts (Rashid, 2016; Shan, 2019). This inconsistent result that the prior studies documented pave the way for one to raise further research question on when does managerial ownership impacts significantly in improving firms' financial performance level. One of the mechanisms that the corporate governance theories suggest to reduce agency costs and enhance companies' bottom line is the board of directors. Accordingly, corporate boards play a vital role in firms' internal governance because its decisions are directly related to various organisational outcomes. Thus, a board of directors occupy the pinnacle position in ensuring the best corporate governance practices (Gillan, 2006; Jensen, 1993). 
More specifically, agency theory opines that board independence can be achieved by employing a substantial number of independent directors on corporate boards. These types of directors have a wealth of experience, technical knowledge and are not under the control of management. Therefore, according to this perspective, independent directors are more vigilant in monitoring the actions and policy decisions of firms' managers (Bathala \& Rao, 1995; Chen, 2014). Likewise, the resource dependency literature highlights that independent or outside directors have the incentives and networking ability to link firms to diverse resources that they require to improve their performance (Bhatt \& Bhattacharya, 2015; Pfeffer \& Salancik, 2003). Hence, from the predictions of these two theories, one may expect the presence of independent directors on boards to neutralise the entrenchment motive of firms' managers, and also to assists firms in obtaining both pecuniary and non-pecuniary benefits from the external environment to promote their value. Accordingly, this study provides further insights into the literature by empirically investigating how the interaction between board independence and managerial ownership may influence companies' financial performance level. By doing so, this study attempts to account for the contradictory views that the existing studies documented regarding the effect of managerial ownership on firms' performance.

Moreover, this study focuses on the firms listed on the Nigerian Stock Market for several reasons. First of all, the Nigerian corporate environment is associated with less corporate disclosure due to the weak institutional structure and an ineffective market for corporate control (Abdullahi et al., 2018; Miko \& Hasnah, 2016; Odeleye, 2018). In this way, this paper conjectures that ineffective market for corporate control may give managers of the Nigerian firms an incentive to pursue sub-optimal policies may affect firms' value. In addition, the corporate governance framework guiding the conduct of companies in the country expressly states that companies should constitute their boards with a higher proportion of outside directors to strengthen their governance system. Although previous studies in Nigeria generated predictions on the association between managerial ownership and firms' performance. However, these studies mainly focus on the direct relationship and basically employed static estimation methods (Adebiyi \& Sunday, 2011; Alhaji \& Sani, 2018; Gugong et al., 2014; Okewale et al., 2020; Sanda et al., 2010).

More importantly, the literature establishes that firm performance and managerial ownership may be endogenously determined (Himmelberg et al., 1999; Tong, 2008). Also, managerial ownership may likely to be a function of past values of firms' performance (Shao, 2019; Wintoki et al., 2012). In this circumstance, applying the static estimation techniques may yield biased regression results. This is because OLS and fixed effects frameworks are built on an exogenous assumption. In contrast to the prior studies in Nigeria, this article exploits a generalized method of moments estimator (GMM). Thus, accounting for endogeneity and reverse causality effect embedded in the association between firms' performance and managerial shareholding. The results of this study show that managerial and performance is negatively related. Likewise, this research extends the literature by providing further explanations on when does managerial ownership is of benefit to firms. In particular, this study found that at a higher level of board independence, managerial shareholding enhances firms' bottom line.

\section{Literature review and Hypotheses development}

The agency theory argued that the separation between ownership and control of firms' resources gives managers an incentive to engage in maximising their personal goals at the expenses of the shareholders' wealth (Fama \& Jensen, 1983; Short \& Keasey, 1999). This instance leads to agency conflicts between managers and shareholders. One of the mechanisms suggested by the agency literature to control this inherent conflict is managerial ownership (Himmelberg et al., 1999). However, the agency theory documented two opposing views regarding the effect of managerial ownership on firm' performance: the alignment hypothesis and the entrenchment approach. In particular, the alignment perspective has the notion that managers have less incentive to divert resources to their benefits when having a considerable proportion of equity ownership in the firms they are managing (Jensen \& Meckling, 1976; Tong, 2008). In this way, managerial ownership may help in aligning the interests of shareholders and managers, which in turn, improving firms' performance.

On the hand, the entrenchment hypothesis observed that high managerial ownership promotes managerial entrenchment which may pave the way for managers to pursue policies that can decrease firms' value (Fahlenbrach \& Stulz, 2009; Shleifer \& Vishny, 1989; Stulz, 1988). Consistent with the 
conjecture of the entrenchment model, a large stream of the literature argued that higher managerial shareholding enables mangers to have discretion over firms' policies. These studies emphasised that a higher level of managerial ownership gives rise to the managers' excessive perquisite consumptions, agency conflicts, and thereby adversely influencing companies' performance level (Cui \& Mak, 2002; Fauzi \& Locke, 2012; Shan, 2019). Given this evidence, this paper formulates the hypothesis that:

\section{$H_{1}$ : Managerial ownership has a significant negative effect on performance.}

Moreover, regarding the effect of board independence on firms' value, both agency and resources dependency theories stressed that corporate boards with a considerable number of independent directors are associated with outstanding performance. The independent directors are non-executive board members who do not have an affiliation with the firms they served. More specifically, the agency literature argued that independent directors monitor managers actively due to their wealth of knowledge, expertise and independence. They are regarded as professional referees because they can objectively assess firms' policy decisions (Fama, 1980; Fama \& Jensen, 1983). Thus, these directors compel managers to design policies that can boost firms' performance level. On the other extreme, the resources dependency perspective also looked at how the presence of independent directors assists companies in drawing valuable resources and legitimacy from the external environment (Pfeffer, 1973; Pfeffer \& Salancik, 2003). Outside directors are purposely employed to serve on corporate boards due to their acceptance, expertise, and skills. Also, firms can obtain legitimacy by appointing individuals with recognition and exceptional capability on their boards to secure wider acceptance and community support (Hillman \& Dalziel, 2003; Singh, 2007). In sum, the resources dependency approach focuses on the role of independent directors in linking firms to strategic resources that they require for their growth and development.

Accordingly, empirical evidence showed that as the number of independent directors on boards rises, companies' financial performance also increases (Jackling \& Johl, 2009; Kao et al., 2019; Muniandy \& Hillier, 2015; Pearce \& Zahra, 1992). In the same vein, a stream of the literature suggested that the presence of outside directors on corporate boards mitigates earnings manipulations by managers, reduces information asymmetry between firms and investors. In this context, studies found that board independence promotes corporate disclosure and lowers information asymmetry, which in turn reduces the shareholder-mangers agency conflicts (Buertey \& Pae, 2020; Elbadry et al., 2015; Wu et al., 2019). Moreover, findings demonstrate that the stringent monitoring by independent directors mitigates the managers' moral hazard behaviour in the form of excessive perquisites consumptions and underinvestment practices (Alves, 2014; Bzeouich et al., 2019; Jaggi et al., 2009; Klein, 2002). In this way, firms with a higher proportion of independent directors on their boards may be associated with lesser agency conflicts and consequently improving their financial performance level. Given these discussions, this paper predicted that the presence of independent directors on corporate boards may enhance firms' value and can also limit the scope of managerial discretion. Therefore, this study formulated the following hypotheses:

\section{$H_{2}$ : Board independence exerts a strong positive impact on firms' performance level.}

$H_{3}: A$ higher level of board independence moderates the relationship between managerial ownership and firm performance.

Furthermore, another corporate governance mechanism that can influence firms' performance is board members' size. Board size refers to the number of persons that constitute a corporate board. The resource dependency theory opined that there is a positive relationship between board size and board diversity. Hence, companies should set-up larger boards to enable them to attract diverse resources and expertise from board composition to improve their profitability (Al-Bassam et al., 2018; Zahra \& Pearce, 1989). On the contrary, the agency theory cautioned firms not to have boards with more than ten members because oversized boards suffer from poor coordination and ineffective monitoring (Lipton \& Lorsch, 1992; Yermack, 1996). According to this paradigm, larger board size weakens sound corporate governance practices, which may give rise to lower firms' value. In line with the agency framework philosophy, studies reported that as board size increases, companies' profitability ratio decreases (Kao et al., 2019; Pillai \& AlMalkawi, 2018). 
Besides, the extant literature documented that firm size and leverage may also explain the variations of performance across firms. Larger companies are more diversified, have various income streams and enjoy economies of scale. Thus, leading to the conclusion that bigger firms are relatively more profitable (Altaf \& Shah, 2018; Ibhagui \& Olokoyo, 2018; Muniandy \& Hillier, 2015). Concerning the effect of leverage on performance, it is established that profitable firms focus on their retained earnings when they require additional funds. Therefore, this perspective argued that the proportion of debt in firms' capital structure decreases as the profitability level rises (Olokoyo, 2013; Pillai \& Al-Malkawi, 2018; Sheikh \& Wang, 2013).

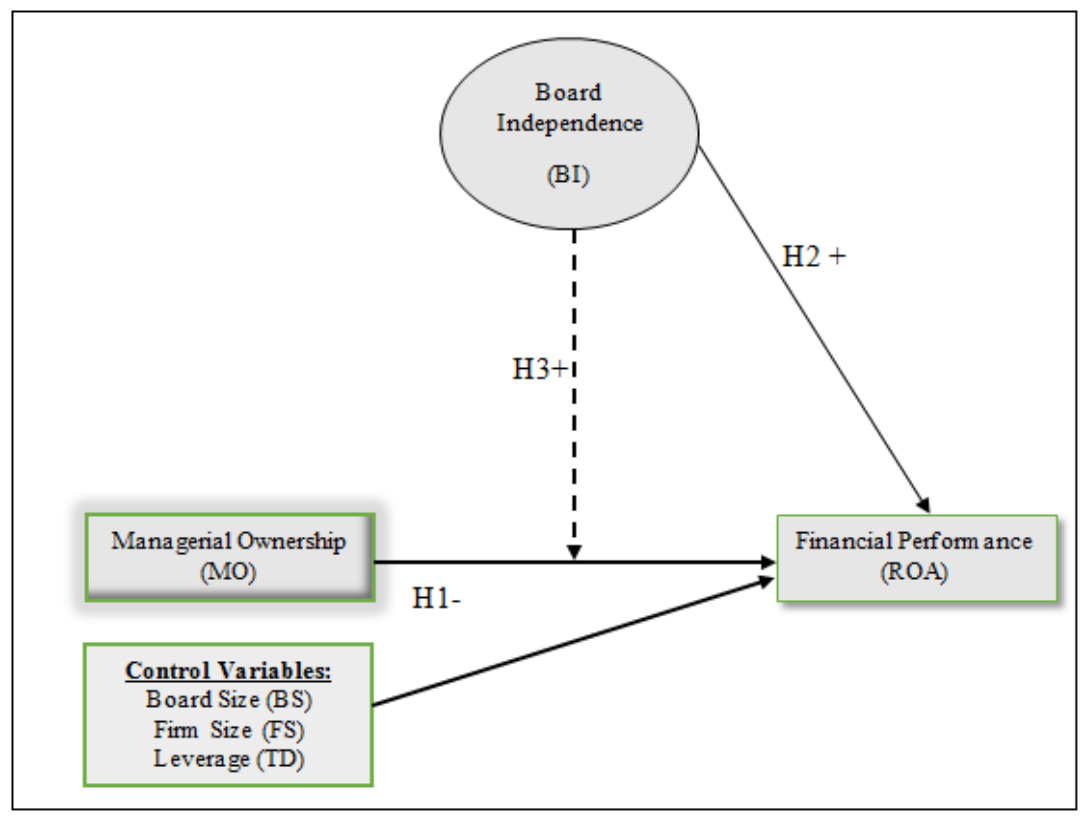

Figure 1.Research Framework

\section{Methodology of research}

\subsection{Data Source, Sample Size and the Study Variables}

This paper obtained its firm-level and corporate governance data from the annual reports and account of the sampled companies covering the period from 2012-2018. The research constructed its sample data in the following manner: In the first place, we focused on companies that have no missing observations within the study time frame. Also, this research dropped firms listed after the year 2012 for us to have firms with a complete data set. Thus, the final sample size comprised of a balanced panel data set of 71 listed firms. Moreover, the description of the study variables is as follows: the main explanatory variable is managerial ownership (MO), while return on assets (ROA) as a measure of firm performance represents the dependent variable. The moderator variable is board independence (BI), while the research employed board size (BS), firm size (FS) and leverage (TD) as control variables. The use of a control variable can minimise specification bias and thereby making a regression result more robust.

\subsection{Econometric Model}

This study exploited a generalised method of moments estimator (GMM) to determine the dynamic relationship between managerial ownership and financial performance. As demonstrated by Ozkan (2001), GMM is the most suitable approach in estimating dynamic relationship among variables. The GMM is of two variants: the difference and system GMM. However, the system GMM framework is relatively more efficient because the technique is associated with more instruments (Arellano \& Bover, 1995). The twostep version of the system GMM is asymptotically even in the presence of heteroscedasticity and autocorrelation (Roodman, 2009). Moreover, the specification tests available to ascertain the validity of GMM estimates include the Hansen test of over-identifying restrictions and the Arellano and Bond test of no second-order serial correlation (Arellano \& Bond, 1991). The null hypothesis of the Hansen statistic is that the instruments are robust and uncorrelated with the error term. Therefore, one may fail to reject the null hypothesis of the Hansen test when its P-value is insignificant. 
On the other hand, the null hypothesis of the Arellano and Bond test suggests that there is no second-order serial correlation in the first differenced error-term. Thus, when the p-value of the Arellano and Bond test is significant, the GMM estimates in question suffer from the second-order serial correlation. Hence, this paper used the two-step GMM framework in determining the impact of managerial ownership on financial performance. The equation one below shows the general form of a dynamic panel model.

$y_{i t}=(\delta-1) y_{i t-1}+\beta X_{i t}+\beta C_{i t}+\mu_{i}+\mu_{t}+\varepsilon_{i t}$

$\mathrm{y}_{i t}$ represents the dependent variable in the model for firm i in t time, ${ }^{y_{i t}-1}$ is the lagged dependent variable, ${ }^{\delta}$ is the adjustment parameter, ${ }_{i t}$ is the independent variable, ${ }^{\beta C_{i t}}$ is the vector of the control variables, $\mu_{i}$ is the firm-specific effect, $\mu_{t}$ is the time effect and the error term is denoted as $\varepsilon_{i t}$. Therefore, by substituting the study variables into the equation (1), this paper specified the following models as follows:

$$
\begin{array}{cl}
R O A_{i t}= & (\delta-1) R O A_{\mathrm{it}-1}+\beta_{1} M O_{\mathrm{it}}+\beta_{2} T D_{\mathrm{it}}+\beta_{3} S I Z E_{\mathrm{it}}+\beta_{4} B S_{\mathrm{it}}+\mu_{i}+\mu_{\mathrm{t}}+\varepsilon_{\mathrm{it}} \\
R O A_{i t}= & \begin{array}{l}
(\delta-1) R O A_{\mathrm{it}-1}+\beta_{1} M O_{\mathrm{it}}+\beta_{2} T D_{\mathrm{it}}+\beta_{3} S I Z E_{\mathrm{it}}+\beta_{4} B S_{\mathrm{it}} \\
+
\end{array}
\end{array}
$$

Where:

ROA $=$ Net profit before interest and taxes over the total assets for firm i in time $\mathrm{t}$;

$\mathrm{MO}=$ is the number of shares owned by executive directors over the total number of shares outstanding for firm i in time $\mathrm{t}$;

$T D=$ book value of total debt/book value of total assets for a firm i in time $t$;

$\mathrm{SIZE}=$ is the firm size, determined as the logarithms of total assets for firm $\mathrm{i}$ in time $\mathrm{t}$;

$B S=$ the total number of board members for firm $i$ in time $t$;

$\mathrm{BI}=$ number of independent directors divided by the board size for firm $\mathrm{i}$ in time $\mathrm{t}$;

$M 0^{*} \mathrm{BI}=$ is the interaction term between managerial ownership and board independence for firm $\mathrm{i}$ in time t.

\section{Criteria for Moderation Effect}

The equation one examines the direct effect of managerial ownership (MO) on firm performance (ROA). The equation two tests the moderating effect of board independence (BI) on the relationship between managerial ownership and performance. This equation captures the direct impact of the moderator variable on the dependent variable. Also, it contains the interaction term (MO*BI) between the primary explanatory variable (MO) and the moderator variable (BI). According to Aguinis et al. (2017), moderating effect occurs when the coefficient of an interaction term is statistically significant. Therefore, this study adopts this approach in its moderation analysis.

\section{Empirical Results and Discussion}

Table 1 exhibits a descriptive statistic of the study variables. The variable (ROA) represents the ratio of net profit before interest and taxes over total assets, and its average value is 0.0583 . This evidence suggests that the firms' average profitability level within the period under review (2012-2012) stood at 6\% approximately. The managerial ownership (MO) indicates an average of about $4 \%$, but with a large deviation across the companies. Also, board independence (BI) shows that $7 \%$ of the firms' board members are independent directors. The variable (TD) represents the ratio of total debt over total assets, and its average value is 0.2822 . This result shows that the firms' total debt stands at $28.22 \%$ of their total capital employed. Also, the variable firm size (FS), which is measured as the logarithms of the firms' total assets reveals a minimum and maximum ratio of 8.4190 and 11.9170 , respectively. The board size (BS) of the sampled companies indicates an average of nine members approximately, with a minimum and a maximum number of four and seventeen board members, respectively. On the other side, Table II below contains the correlation results among our study variables. The evidence suggests that there is no significant association 
across our explanatory variables. Hence, the result reveals that our model specification is free of the multicollinearity problem.

Table 1. Descriptive Statistics

\begin{tabular}{cccccc}
\hline Variable & Mean & Std. Div. & Min. & Max. & Observations \\
\hline ROA & 0.0583 & 0.0510 & -0.1010 & 0.2840 & 497 \\
MO & 0.0419 & 0.1169 & 0.0000 & 6560 & 497 \\
BI & 0.0685 & 0.1133 & 0.0000 & 0.5560 & 497 \\
TD & 0.2822 & 0.1974 & 0.0000 & 0.8918 & 497 \\
SIZE & 10.1110 & 0.7849 & 8.4190 & 11.9170 & 497 \\
BS & 8.5754 & 2.3190 & 4.0000 & 17.0000 & 497 \\
\hline
\end{tabular}

$\mathrm{ROA}=$ return on assets, $\mathrm{MO}=$ managerial ownership, $\mathrm{BI}=$ board independence, $\mathrm{TD}=$ total debt/total assets, $\mathrm{SIZE}=$ firm size and $\mathrm{BS}=$ board size .

Table 2. Correlation Matrix

\begin{tabular}{cccccccc}
\hline Variable & ROA & MO & BI & TD & SIZE & BS & VIF \\
\hline ROA & 1.000 & & & & & & \\
MO & $-0.177^{* * *}$ & 1.000 & & & & & 1.80 \\
BI & $0.209^{* * *}$ & -0.651 & 1.000 & & & & 1.12 \\
TD & $-0.387^{* * *}$ & -0.023 & $0.117^{* * *}$ & 1.000 & & 1.06 \\
SIZE & $0.347^{* * *}$ & $-0.173^{* * *}$ & $0.220^{* * *}$ & 0.031 & 1.000 & & 1.26 \\
BS & $0.093^{* *}$ & $-0.129^{* * *}$ & $0.147^{* * *}$ & $-0.169^{* * *}$ & $0.380^{* * *}$ & 1.000 & 1.23 \\
\hline
\end{tabular}

$\mathrm{ROA}=$ return on assets, $\mathrm{MO}=$ managerial ownership, $\mathrm{BI}=$ board independence,

$=$ total debt $/$ total assets, SIZE $=$ firm size and BS $=$ board size.

$* * * \& * *$ indicate significance at $1 \%$ and $5 \%$ respectively.

Table 3. Regression Results: Two-step System GMM

\begin{tabular}{ccc}
\hline Model & $\mathbf{2}$ & $\mathbf{3}$ \\
\hline ROAi,t-1 & $0.395^{* * *}$ & $0.398^{* * *}$ \\
MO & $(0.070)$ & $(0.068)$ \\
& $-0.025^{* *}$ & $-0.040^{* * *}$ \\
TD & $(0.012)$ & 0.012 \\
& $-0.091^{* * *}$ & $-0.088^{* * *}$ \\
SIZE & $(0.009)$ & $(0.009)$ \\
& $0.019^{* * *}$ & $0.018^{* * *}$ \\
BS & $(0.003)$ & $(0.003)$ \\
& $-0.002^{* * *}$ & $-0.002^{* * *}$ \\
BI & $(0.001)$ & $(0.001)$ \\
& - & 0.021 \\
BI*MO & & $(0.014)$ \\
& & $0.235^{* *}$ \\
Hansen Statistics (P-value) & 0.172 & $(0.109)$ \\
AR1(P-value) & 0.009 & 0.160 \\
AR2 (P-value) & 0.193 & 0.008 \\
Wald Statistics (P-value) & 0.000 & 0.196 \\
Year dummies & Yes & 0.000 \\
Industry dummies & Yes & Yes \\
*** and $* *$ indicate significance at $1 \%$ and $5 \%$ respectively. & Yes \\
The numbers in parenthesis are standard errors robust to heteroscedasticity
\end{tabular}

Table 3 displays the regression results on the direct effect of managerial ownership on performance, as well as the finding on the interaction between managerial ownership and board independence. According to the results, this research fulfils the underlying assumptions of a GMM specification. The Hansen statistic shows an insignificant P-value in both equation two and three. Therefore, this paper fails to reject the null hypothesis of instruments validity. As expected, the P-values of the AR2 in all our models' 
specifications also appear insignificant, which implies that the second-order serial correlation is absent. Thus, revealing that our GMM instrument sets are robust and uncorrelated with the error terms. Moreover, the coefficients of the lagged dependent variable $\left(\mathrm{ROA}_{\mathrm{i}, \mathrm{t}-1}\right)$ in both equations two and three are positive and statistically significant at the $1 \%$ level. This evidence indicates that the past performance of the Nigerian listed companies impacts strongly on their current performance level. In sum, this finding aligns with the conjecture that lagged performance is an essential explanatory variable in determining the dynamic association between managerial ownership and firms' performance (Shao, 2019; Wintoki et al., 2012).

Turning now to the results in equation two, which captures the direct effect of the explanatory variables on the return on assets (ROA). The coefficient of the managerial ownership is negative and significant at the $5 \%$ level. Hence, this study fails to reject its $\mathrm{H} 1$. The finding shows that an increase in managerial ownership decreases the profitability of the Nigerian listed firms. This evidence reinforces the argument of the entrenchment hypothesis that high managerial shareholding promotes managerial discretion and exacerbates agency conflicts, which in turn lowers firms' performance (Cui \& Mak, 2002; Fauzi \& Locke, 2012; Shan, 2019). Also, the regression results reveal a significant negative association between leverage and return on assets (ROA). This empirical finding suggests that debt financing lowers the profitability level of Nigerian listed companies. The evidence supports the argument that the cost of acquiring external borrowing is relatively higher and thus firms' focus more on equity financing to raise their financial performance (Olokoyo, 2013; Sheikh \& Wang, 2013).

However, the coefficient of firm size is positive and significant and thereby signifying that Nigerian listed firms with larger size are associated with a higher profitability level. This empirical finding is consistent with that of Ibhagui \& Olokoyo (2018) and Muniandy \& Hillier (2015). These studies reported that larger companies enjoy economies of scale on production costs, which may eventually impact positively on their financial performance. On the contrary, the results show significantly that as board size increases, the profitability level of the Nigerian listed companies decreases. This finding contradicts the resource dependency theory's philosophy and aligns with the agency theory assumption that larger board size lowers firms' performance (Jensen, 1993). Likewise, the empirical result supports the findings that larger boards are associated with poor coordination and slower decision-making and thereby jeopardising firms' financial outcomes (Pillai \& Al-Malkawi, 2018; Yermack, 1996).

Regarding the regression outcome in equation two, board independence reveals a positive but insignificant coefficient, and thus the result does not support our $\mathrm{H}_{2}$. Nevertheless, the positive effect of board independent on return on assets (ROA) implies that the presence of independent directors on the board of directors of the Nigerian listed firms may enhance their performance level. Moreover, the interaction between managerial ownership and board independence yields a positive result. This evidence indicates that board independence moderates positively the relationship between managerial ownership and firms' financial performance. The finding can be interpreted to mean that as the proportion of indent directors rises, the influence of managerial ownership on profitability ratio of the Nigerian listed firms also increases. Thus, this moderating effect reinforces the arguments of both agency and resources dependency theories that firms with a considerable percentage of independent directors are associated with outstanding performance (Hillman \& Dalziel, 2003; Jaggi et al., 2009). Again, the positive moderating result suggests that independent directors' superior monitoring may compel firms' managers to design policies that can improve performance level. Given this evidence, this paper fails to reject its $\mathrm{H}_{3}$ and instead concludes that board independence moderates the managerial ownership-performance relationship of the Nigerian firms.

\section{Conclusions}

This article investigated the moderating role of board independence on the relationship between managerial shareholding and financial performance of the Nigerian listed companies. The paper analysed the balanced panel data of the sampled firms covering the period from 2012-2018 using the GMM estimation techniques. The article provided useful insights into the corporate governance literature as follows: First of all, the use of GMM has permitted us to appropriately control for endogeneity and reverse causality embedded in the relationship between managerial ownership and firms' performance. The evidence from this research showed that a higher level of managerial ownership lower performance of 
firms which is consistent with the premises of the entrenchment model. Likewise, as predicted by both agency and resources dependency theories, our results showed that board independence is an effective corporate governance mechanism that cans constraint the entrenchment motive of firms' managers. Overall, this study extends the literature on the determinants of firms' performance by empirically showing that the interaction between managerial ownership and board independence is an important mechanism that can yield a positive impact on the return on assets (ROA). Given that this research focuses only on managerial ownership, further studies should explore other aspects of corporate ownership, such as institutional and foreign ownership.

\section{References}

1. Abdullahi, Y. U., Ishak, R., \& Sawandi, N. (2018). Outsider vs Insider: Does Firm Governance Matter? Business and Economic Horizons, 14(3), 689-699.

2. Adebiyi, A., \& Sunday, K. (2011). Ownership Structure and Performance: Evidence from Nigerian Listed Companies. Corporate Ownership and Control, 8(4), 391-400.

3. Aguinis, H., Edwards, J. R., \& Bradley, K. J. (2017). Improving Our Understanding of Moderation and Mediation in Strategic Management Research. Organizational Research Methods, 20(4), 665-685.

4. Al-Bassam, W. M., Ntim, C. G., Opong, K. K., \& Downs, Y. (2018). Corporate Boards and Ownership Structure as Antecedents of Corporate Governance Disclosure in Saudi Arabian Publicly Listed Corporations. Business and Society, 57(2), 335-377.

5. Alhaji, S. S., \& Sani, G. (2018). Managerial Ownership and Financial Performance of Listed Manufacturing Firms in Nigeria. International Journal of Academic Research in Business and Social Sciences, $8(9), 1227-1243$.

6. Altaf, N., \& Shah, F. A. (2018). Ownership Concentration and Firm Performance in Indian Firms: Does Investor Protection Quality Matter? Journal of Indian Business Research, 10(1), 33-52.

7. Alves, S. (2014). The Effect of Board Independence on the Earnings Quality: Evidence from Portuguese Listed Companies. Australasian Accounting, Business and Finance Journal, 8(3), 23-44.

8. Arellano, M., \& Bond, S. (1991). Some Tests of Specification for Panel Data: Monte Carlo Evidence and an Application to Employment Equations. The Review of Economic Studies, 58(2), 277-297.

9. Arellano, M., \& Bover, O. (1995). Another Look at the Instrumental Variable Estimation of ErrorComponents Models. Journal of Econometrics, 68, 29-51.

10.Bathala, C. T., \& Rao, R. P. (1995). The Determinants of Board Composition: An Agency Theory Perspective. Managerial and Decision Economics, 16(1), 59-69.

11.Bhatt, R. R., \& Bhattacharya, S. (2015). Do Board Characteristics Impact Firm Performance? An Agency and Resource Dependency Theory Perspective. Asia-Pacific Journal of Management Research and Innovation, 11(4), 274-287.

12.Buertey, S., \& Pae, H. (2020). Corporate Governance and Forward-Looking Information Disclosure: Evidence from a Developing Country. Journal of African Business, 21(4), 1-16.

13.Bzeouich, B., Lakhal, F., \& Dammak, N. (2019). Earnings Management and Corporate Investment Efficiency: Does the Board of Directors Matter? Journal of Financial Reporting and Accounting, 17(4), 650670.

14.Chen, D. (2014). The Non-monotonic Effect of Board Independence on Credit Ratings. Journal of Financial Services Research, 45(2), 145-171.

15.Chijoke-Mgbame, A. M., \& Mgbame, C. O. (2018). Discretionary Environmental Disclosures of Corporations in Nigeria. International Journal of Disclosure and Governance, 15(4), 252-261.

16.Cui, H., \& Mak, Y. T. (2002). The Relationship Between Managerial Ownership and Firm Performance in High R\&D Firms. Journal of Corporate Finance, 8(4), 313-336.

17.Elbadry, A., Gounopoulos, D., \& Skinner, F. (2015). Governance Quality and Information Asymmetry. Financial Markets, Institutions and Instruments, 24(2), 127-157.

18.Fahlenbrach, R., \& Stulz, R. M. (2009). Managerial Ownership Dynamics and Firm Value. Journal of Financial Economics, 92(3), 342-361.

19.Fama, E. F. (1980). Agency Problems and the Theory of the Firm. Journal of Political Economy, 88(2), 288-307. 
20.Fama, E. F., \& Jensen, M. C. (1983). Separation of Ownership and Control. Journal of Law and Economics, 26(2), 301-325.

21.Fauzi, F., \& Locke, S. (2012). Board Structure, Ownership Structure and Firm Performance: A Study of New Zealand Listed-Firms. Asian Academy of Management Journal of Accounting and Finance, 8(2), 4367.

22.Gillan, S. L. (2006). Recent Developments in Corporate Governance: An Overview. Journal of Corporate Finance, 12(3), 381-402.

23.Gugong, B. K., Arugu, L. O., \& Dandago, K. I. (2014). The Impact of Ownership Structure on the Financial Performance of Listed Insurance Firms in Nigeria. International Journal of Academic Research in Accounting, Finance and Management Sciences, 4(1), 409-416.

24.Haghighi, A., \& Safari Gerayli, M. (2020). Managerial Ownership and Stock Price Crash Risk: A Case of Iranian Firms. International Journal of Islamic and Middle Eastern Finance and Management, 13(1), 4255.

25.Hillman, A. J., \& Dalziel, T. (2003). Boards of Directors and Firm Performance: Integrating Agency and Resource Dependence Perspectives. The Academy of Management Review, 28(3), 383-396.

26. Himmelberg, C. P., Hubbard, R. G., \& Palia, D. (1999). Understanding the Determinants of Managerial Ownership and the Link between Ownership and Performance. Journal of Financial Economics, 53, 353-384.

27.Ibhagui, O. W., \& Olokoyo, F. O. (2018). Leverage and Firm Performance: New Evidence on the Role of Firm Size. North American Journal of Economics and Finance, 45, 57-82.

28.Jackling, B., \& Johl, S. (2009). Board Structure and Firm Performance: Evidence from India's Top Companies. Corporate Governance: An International Review, 17(4), 492-509.

29.Jaggi, B., Leung, S., \& Gul, F. (2009). Family Control, Board Independence and Earnings Management: Evidence Based on Hong Kong Firms. Journal of Accounting and Public Policy, 28, 281-300.

30.Jensen, M. C. (1993). The Modern Industrial Revolution, Exit, and the Failure of Internal Control Systems. The Journal of Finance, 48(3), 831-880.

31.Jensen, M. C., \& Meckling, W. H. (1976). Theory of the Firm: Managerial Behavior, Agency Costs and Ownership Structure. Journal of Financial Economics, 3(4), 305-360.

32.Kao, M.-F., Hodgkinson, L., \& Jaafar, A. (2019). Ownership Structure, Board of Directors and Firm Performance: Evidence from Taiwan. Corporate Governance (Bingley), 19(1), 189-216.

33.Klein, A. (2002). Audit Committee, Board of Director Characteristics, and Earnings Management. Journal of Accounting and Economics, 33, 375-400.

34.Lipton, M., \& Lorsch, J. W. (1992). A Modest Proposal for Improved Corporate Governance. The Business Lawyer, 42(1), 59-78.

35.Miko, N., \& Hasnah, K. (2016). Corporate Governance Mechanisms, Sensitive Factors and Earnings management in Nigerian Oil and Gas Industry. Corporate Ownership and Control, 13(2), 39-48.

36.Muniandy, B., \& Hillier, J. (2015). Board Independence, Investment Opportunity Set and Performance of South African Firms. Pacific-Basin Finance Journal, 35, 108-124.

37.Mustapha, M., \& Ahmad, A. C. (2011). Agency Theory and Managerial Ownership: Evidence from Malaysia. Managerial Auditing Journal, 26(5), 419-436.

38.Odeleye, A. T. (2018). Quality of Corporate Governance on Dividend Payouts: The Case of Nigeria. African Development Review, 30(1), 19-32.

39.Okewale, J. A., Mustapha, O. A., \& Aina, G. O. (2020). Ownership Structure and Financial Performance of quoted Food and Beverage Firms in Nigeria. KIU Journal of Social Sciences, 6(2), 263-273.

40.Olokoyo, F. O. (2013). Capital Structure and Corporate Performance of Nigerian Quoted Firms : A Panel Data Approach. African Development Studies, 25(3), 358-369.

41.Ozkan, A. (2001). Determinants of Capital Structure and Adjustment to Long Run Target: Evidence from UK Company Panel Data. Journal of Business Finance and Accounting, 28(2), 175-198.

42.Pearce, J. A., \& Zahra, S. A. (1992). Board Composition from a Strategic Contingency Perspective. Journal of Management Studies, 29(4), 411-438.

43.Pfeffer, J. (1973). Size, Composition, and Function of Hospital Boards of Directors: A Study of Organization- Environment Linkage. Administrative Science Quarterly, 18(3), 349-364. 
44.Pfeffer, J., \& Salancik, G. R. (2003). The External Control of Organizations: A Resource Dependence Approach. California: Standford University Press.

45.Pillai, R., \& Al-Malkawi, H. A. N. (2018). On the Relationship Between Corporate Governance and Firm Performance: Evidence from GCC Countries. Research in International Business and Finance, 44, 394410.

46.Rashid, A. (2016). Managerial Ownership and Agency Cost: Evidence from Bangladesh. Journal of Business Ethics, 137(3), 609-621.

47.Roodman, D. (2009). How To DO Xtabond2: An Introduction to Difference and System GMM in Stata. The Stata Journal, 9(1), 86-136.

48.Sanda, A. U., Mikailu, A. S., \& Tukur, G. (2010). Corporate Governance Mechanisms and Firms' Financial Performance in Nigeria. Afro-Asian Journal of Finance and Accounting, 2(1), 22-39.

49.Shan, Y. G. (2019). Managerial Ownership, Board Independence and Firm Performance. Accounting Research Journal, 32(2), 203-220.

50.Shao, L. (2019). Dynamic Study of Corporate Governance Structure and Firm Performance in China: Evidence from 2001-2015. Chinese Management Studies, 13(2), 299-317.

51.Sheikh, N. A., \& Wang, Z. (2013). The Impact of Capital Structure on Performance: An Empirical Study of Non-Financial Listed Firms in Pakistan. International Journal of Commerce and Management, 23(4), 354-368.

52.Shleifer, A., \& Vishny, R. W. (1989). Management Entrenchment: The Case of Manager-Specific Investments. Journal of Financial Economics, 25, 123-139.

53.Short, H., \& Keasey, K. (1999). Managerial Ownership and the Performance of Firms: Evidence from the UK. Journal of Corporate Finance, 5(1), 79-101.

54.Singh, V. (2007). Ethnic Diversity on Top Corporate Boards: A Resource Dependency Perspective. The International Journal of Human Resource Management, 18(12), 2128-2146.

55.Stulz, R. M. (1988). Managerial Control of Voting Rights: Financing Policies and the Market for Corporate Control. Journal of Financial Economics, 20, 25-54.

56.Tong, Z. (2008). Deviations from Optimal CEO Ownership and Firm Value. Journal of Banking and Finance, 32(11), 2462-2470.

57.Wintoki, M. B., Linck, J. S., \& Netter, J. M. (2012). Endogeneity and the Dynamics of Internal Corporate Governance. Journal of Financial Economics, 105(3), 581-606.

58.Wu, K., Sorensen, S., \& Sun, L. (2019). Board Independence and Information Asymmetry: Family Firms vs Non-Family Firms. Asian Review of Accounting, 27(3), 329-349.

59.Yermack, D. (1996). Higher Market Valuation for Firms with a Small Board of Directors. Journal of Financial Economics, 40, 185-211.

60.Zahra, S. A., \& Pearce, J. A. (1989). Boards of Directors and Corporate Financial Performance: A Review and Integrative Model. Journal of Management, 15(2), 291-334. 